\title{
Platelet-Activating Factor Regulates Chloride Transport in Colonic Epithelial Cell Monolayers
}

\author{
ERIKA C. CLAUD, DAN LI, YU XIAO, MICHAEL S. CAPLAN, AND TAMAS JILLING \\ Division of Pediatric Gastroenterology and Nutrition, Massachusetts General Hospital East Building, \\ Charlestown, Massachusetts 02129, U.S.A.; Department of Pediatrics and Evanston Northwestern \\ Healthcare Research Institute, Evanston Hospital Northwestern University Medical School, \\ Evanston, Illinois 60201, U.S.A.
}

\begin{abstract}
ABST
Platelet-activating factor (PAF) has been implicated in the
pathogenesis of gastrointestinal diseases such as necrotizing
enterocolitis, Crohn's disease, and ulcerative colitis. However,
neither the physiologic role of PAF in the intestine, nor the
mechanisms by which PAF participates in the pathogenesis of
disease are well understood. The aim of the present study was to
determine the direct effect of PAF on intestinal epithelial cell ion
transport, and to delineate the mechanisms of regulation. Ion
transport was evaluated by measuring short circuit current $\left(\mathrm{I}_{\mathrm{sc}}\right.$ ) in
HT29-CL19A cell monolayers using Ussing chambers. PAF
receptor polarity was assessed using domain-selective biotinyla-
tion followed by immunoprecipitation and streptavidin blotting
of intact epithelial monolayers. PAF (1-200 $\mu \mathrm{M}$ ) stimulated $\mathrm{I}_{\mathrm{sc}}$
that followed the direction of a $\mathrm{Cl}^{-}$gradient and was specifically
inhibited by the $\mathrm{Cl}^{-}$channel blockers glybenclamide, $2,2^{\prime}$ imi-
nodibenzoic acid and 4,4' diisothiocyanostilbene-2, $2^{\prime}$ disulfonic
acid, but was unaffected by the inhibition of prostaglandin syn-
thesis with indomethacin. Stimulated $\mathrm{I}_{\mathrm{sc}}$ was only detected after
apical addition of $\mathrm{PAF}^{-}$correlating with the results of biotinyla-
tion experiments indicating an exclusive apical polarity of the
\end{abstract}
PAF receptor. PAF receptor antagonists CV6209 and octylonium bromide abolished PAF-stimulated $\mathrm{I}_{\mathrm{sc}}$. Thus, mucosal acting PAF directly and specifically stimulates ion transport via activation of an apical $\mathrm{Cl}^{-}$channel in intestinal epithelial cell monolayers independent of prostaglandin biosynthesis. (Pediatr Res 52: 155-162, 2002)

\section{Abbreviations}

DIDS, 4,4' diisothiocyanostilbene-2, 2' disulfonic acid

DPC, 2,2' iminodibenzoic acid

IBD, inflammatory bowel disease

$\mathbf{I}_{\text {sc }}$, short circuit current

NEC, necrotizing enterocolitis

PAF, platelet-activating factor

PAF-AH, platelet-activating factor acetylhydrolase

PAFR, platelet-activating factor receptor

PBSCM, PBS supplemented with $1 \mathrm{mM} \mathrm{CaCl} 2$ and $1 \mathrm{mM}$

$\mathrm{MgCl}_{2}$

pIGR, polymeric immunoglobulin receptor

$\mathbf{R}_{\text {te, }}$ transepithelial resistance
PAF 1-O-alkyl-2-acetyl-sn glycero-3-phosphocholine is a phospholipid intra- and intercellular mediator implicated in the pathology of intestinal diseases such as NEC (1) and IBD (2). It has been shown that PAF levels are elevated in infants with NEC (3). In rats, exogenous PAF given intravenously results in ischemic bowel necrosis (4). Furthermore, studies using a rat model of NEC have shown that enteral administration of PAFR antagonists reduces the incidence of $\operatorname{NEC}(5,6)$. Recently, elevated PAF levels have been found in stool samples of patients with IBD (2). Correlating with these findings, de-

Received June 1, 2001; accepted February 18, 2002.

Correspondence: Tamas Jilling, M.D., Department of Pediatrics, Evanston Hospital, Northwestern University Medical School, 2650 Ridge Ave., Evanston, IL 60201, U.S.A.; e-mail: tjilling@northwestern.edu

Supported by Grant \#6-FY99-278 from the March of Dimes Foundation, by National Institutes of Health Grant RO1-HD37581-01A1, and by the Jessica Jacobi Golder endowment.

DOI: 10.1023/01.PDR.0000023173.89966.19 creased levels of the PAF degrading enzyme, PAF-AH, have been observed in the distal ileum and serum samples of patients suffering from Crohn's disease (7). In addition, lexipafant, a PAFR antagonist significantly reduced mucosal damage in an experimental model of colitis (8).

Once activated, PAF initiates production of other inflammatory mediators such as tumor necrosis factor- $\alpha$, prostaglandins, thromboxane, and complement. It is unknown, however, whether the pathologic consequences of elevated PAF levels in the intestine are only the result of the initiation of an inflammatory cascade, or whether PAF itself may have a direct effect on intestinal epithelial cells. Other inflammatory mediators have been shown to alter critical hallmark functions of the intestinal epithelium, e.g. ion transport $(9,10)$. Studies of PAF on tissue explants have also implied PAF induced ion transport. Notably, isolated rat jejunum (11) as well as human, rabbit, and rat colon have all demonstrated PAF-stimulated $\mathrm{Cl}^{-}$secretion (12-14). 
However, despite extensive investigation of the effects of PAF on tissue and organ systems, specific effects at the intestinal epithelial cell level are poorly understood. It is difficult to extrapolate a direct PAF effect on epithelial cells from studies on tissue specimens because tissue samples incorporate multiple cell types with many interactions. PAF has been shown to stimulate $\mathrm{Cl}^{-}$secretion in human and rat colonic explants, but these effects were blocked by indomethacin and by a thromboxane $A_{2}$ synthase inhibitor, implying a significant role for intermediary mediators $(12,13)$. Thus, it is unclear at present whether PAF-induced transepithelial $\mathrm{Cl}^{-}$transport in intact intestine represents a direct interaction of PAF with intestinal epithelial cells.

PAFR are abundantly expressed in the epithelial cells of the small intestine and colon, as well as in cultured epithelial cells lines (15). To examine the effect of PAF on ion transport, specifically in intestinal epithelial cells, we mounted HT29CL19A human colonic adenocarcinoma cell monolayers in Ussing chambers and measured PAF-induced transepithelial ion transport. Specifically, we determined that PAF directly stimulates transcellular active ion transport, documented PAFR expression and apical polarity in epithelial cell monolayers, and identified $\mathrm{Cl}^{-}$as the charge carrier for PAF-induced ion transport.

\section{MATERIALS AND METHODS}

Materials. DIDS was obtained from Calbiochem (San Diego, CA, U.S.A.). PAF, glybenclamide, amphotericin B, 8-(4Chlorophenylthio) adenosine 3': 5'-cyclic monophosphate (cptcAMP), indomethacin, and the MAb to the secretory piece of the human polymeric immunoglobulin receptor were obtained from Sigma Chemical (St. Louis, MO, U.S.A.). CV-6209 and octylonium bromide were from Biomol (Plymouth Meeting, PA, U.S.A.). DPC was obtained from Aldrich (St. Louis, MO, U.S.A.). The polyclonal antibody to human PAFR was from Cayman Chemical (Ann Arbor, MI, U.S.A.), anti-rabbit IgGFITC was from DAKO (Carpinteria, CA, U.S.A.), and streptavidin-HRP conjugate was from Pierce Chemical (Rockford, IL, U.S.A.). Carbamyl PAF was purchased from Alexis Corporation (San Diego, CA, U.S.A.). Human recombinant PAF-AH was a generous gift from Dr. Gary Peterman (ICOS Corporation, Seattle, WA, U.S.A.).

Epithelial cell culture. HT29-CL19A cells originate from the subcloning of a human colonic adenocarcinoma cell line and display a highly differentiated phenotype, unlike the original HT29 cells (16). Cells were cultured in Dulbecco's modified Eagle media with $10 \%$ fetal bovine serum, penicillin 50 $\mathrm{U} / \mathrm{mL}$, and streptomycin $50 \mu \mathrm{g} / \mathrm{mL}$. Cells were grown at $37^{\circ} \mathrm{C}$ in a $5 \% \mathrm{CO}_{2}$ atmosphere. Media was replaced every $48 \mathrm{~h}$, and cells were passaged every $7 \mathrm{~d}$. For Ussing chamber experiments, $200 \mu \mathrm{L}$ of cell suspension containing $5 \times 10^{5}$ cells was plated on top of six-well Snapwell filters (12-mm diameter, 0.4- $\mu \mathrm{m}$ pore size, Corning Life Sciences, Acton, MA, U.S.A.). Culturing HT29-CL19A cells for 8-11 d resulted in the formation of a polarized epithelial monolayer with welldeveloped mucosal and serosal membranes. HT29-CL19A monolayers were studied when resistances were $>250 \Omega / \mathrm{cm}^{2}$.
$\boldsymbol{I}_{s c}$ and $\boldsymbol{R}_{t e}$ measurements. After 8-11 d of incubation, current and resistance measurements were obtained using an Ussing chamber system equipped with digital data acquisition software that also allows software control of clamp electronics (Physiologic Instruments, San Diego, CA, U.S.A.). A blank filter was initially inserted to make adjustments for fluid resistance and voltage asymmetry, and then filters with cell monolayers were placed between chambers filled with $3 \mathrm{~mL}$ of buffer solution. The standard physiologic buffer used contained $116 \mathrm{mM} \mathrm{NaCl}, 5.4 \mathrm{mM} \mathrm{KCl}, 0.4 \mathrm{mM} \mathrm{MgCl}_{2}, 1.8 \mathrm{mM} \mathrm{CaCl}_{2}$, $5.5 \mathrm{mM}$ Glucose, $26 \mathrm{mM} \mathrm{NaHCO}_{3}$, and $0.9 \mathrm{mM} \mathrm{NaH}_{2} \mathrm{PO}_{4}$. $\mathrm{I}_{\mathrm{sc}}$ was recorded in voltage clamp mode. $\mathrm{R}_{\mathrm{te}}$ was evaluated using $10-\mathrm{mV}$ pulses every $20 \mathrm{~s}$. $\mathrm{I}_{\mathrm{sc}}$ recordings presented in the figures are representations of single readings and are the result of digital data acquisition of actual current before the voltage pulse; therefore, the current spikes elicited by the voltage pulses are not displayed. When transport was evaluated under asymmetric buffer ion conditions, compensation for bridges and fluid resistance was performed under identical asymmetric ion conditions. $\mathrm{I}_{\mathrm{sc}}$ and $\mathrm{R}_{\mathrm{te}}$ were recorded and analyzed using the Acquire and Analyze program, (Physiologic Instruments). A positive current was defined as the movement of negative ions from the serosal to the mucosal compartment or the flow of positive ions in the opposite direction.

Identification of PAFR mRNA using Reverse-Transcriptase PCR and restriction digestion mapping. Total RNA was extracted by RNA-extracting agent STAT-60 (Tel Test B, Friendswood, TX, U.S.A.), according to the manufacturer's instructions. RNA integrity was verified by electrophoresis in $1 \%$ agarose gel. For each sample, $3 \mu \mathrm{g}$ total RNA was reverse transcribed using Moloney-murine leukemia virus reverse transcriptase (Invitrogen, Carlsbad, CA, U.S.A.). cDNA was amplified by 35 cycles of PCR with AmpliTaq DNA polymerase using sense 5'-TATAACCGCTTCCAGGCAGT-3' and antisense 5'-GAAACAGTAGATAACAGGGTC-3' primers, respectively (17). The size of the predicted PAFR PCR product is $549 \mathrm{bp}$. After PCR, the PAFR PCR products were digested with PuvII or AvaII restriction enzymes at $37^{\circ} \mathrm{C}$ for $60 \mathrm{~min}$ and were separated by electrophoresis on a $1.2 \%$ agarose gel containing 1:10,000 diluted SYBR Green I (QIAGEN, Valencia, CA, U.S.A.).

Cell-surface biotinylation, immunoprecipitation, and streptavidin blotting of PAFR. Cell-surface biotinylation was performed using cells grown on Snapwell membranes as described for Ussing chamber experiments. Cells were washed in ice-cold PBSCM. Sulfo-NHS-LC-biotin $(1 \mathrm{mM})$ in PBSCM was then added to either the mucosal or serosal chamber. After incubation for $30 \mathrm{~min}$ on ice, cells were washed in ice-cold PBSCM, and blocked with $100 \mathrm{mM}$ glycine in PBSCM for 30 min on ice. For immunoprecipitation, cells were lysed for 30 min at $4{ }^{\circ} \mathrm{C}$ in buffer containing $20 \mathrm{mM}$ HEPES, $150 \mathrm{mM} \mathrm{NaCl}$, $1 \mathrm{mM}$ EDTA, and 1\% Nonidet P-40 (pH 7.4) supplemented with $10 \mu \mathrm{g} / \mathrm{mL}$ aprotinin, $10 \mu \mathrm{g} / \mathrm{mL}$ leupeptin, and $10 \mu \mathrm{g} / \mathrm{mL}$ 4-(2-aminoethyl)-benzenesulfonyl fluoride. Lysates were then centrifuged at $16,000 \times g$ for $5 \mathrm{~min}$, and supernatants were supplemented with $1 / 4$ volume of $5 \times$ RIPA buffer [ $250 \mathrm{mM}$ Tris (pH 7.5), $120 \mathrm{mM}$ sodium deoxycholate, $600 \mathrm{mM} \mathrm{NaCl}$, $5 \%$ Triton X-100 (vol./vol.) and $0.5 \%$ SDS]. After adding 0.5 
$\mu \mathrm{g}$ anti-PAFR polyclonal antibody, $10 \mu \mathrm{L}$ of anti-pIGR containing ascites fluid (basolateral biotinylation positive control), or an equal concentration of rabbit/mouse nonimmune $\operatorname{IgG}$ (negative control), lysates were incubated at $4^{\circ} \mathrm{C}$ for $1 \mathrm{~h}$ on a rotating shaker, followed by the addition of $20 \mu \mathrm{L}$ protein $\mathrm{G}$ agarose (50\% slurry) and incubation for an additional $1 \mathrm{~h}$. Beads were collected with centrifugation at $1000 \times g$ for 2 min, and washed three times using $1 \times$ RIPA. Pellets were resuspended in equal volumes of reducing SDS sample buffer [60 mM Tris (pH 6.8), 2\% SDS, $5 \% \beta$-mercapto-ethanol, $0.1 \%$ bromphenol blue, $50 \%$ glycerol], heated for $5 \min$ to $95^{\circ} \mathrm{C}$, resolved on reducing SDS-PAGE, then transferred to polyvinylidene fluoride membranes (Bio-Rad, Cambridge, MA, U.S.A.). Membranes were overlaid with streptavidin-horse radish peroxidase conjugates $(100 \mathrm{ng} / \mathrm{mL})$, incubated for $1 \mathrm{~h}$, then washed three times with $0.5 \%$ Tween 20 in Tris-buffered saline. Blots were visualized using the ECL Plus chemiluminescence reagent (Amersham Pharmacia Biotech, Oakville, ON, Canada) and a Storm 860 Phosphor Imager (Molecular Dynamics, Sunnyvale, CA, U.S.A.).

Statistics. Results are presented as mean values \pm SEM. For statistical analysis, $t$ test or ANOVA with Tukey's multiple comparison tests was used. Significance was defined as $p<$ 0.05 . $\mathrm{I}_{\mathrm{sc}}$ values were analyzed and are presented as changes from the values measured immediately before the respective treatment, or $\Delta \mathrm{I}_{\mathrm{sc}}$.

\section{RESULTS}

Comparison of PAF- and cAMP-induced $I_{s c^{\circ}}$ HT29-CL19A monolayers exhibited a $7.9 \pm 0.2 \mu \mathrm{A} / \mathrm{cm}^{2}$ baseline $\mathrm{I}_{\mathrm{sc}}$. Monolayers were treated with PAF $(10 \mu \mathrm{M})$ in sequence with cpt-cAMP $(300 \mu \mathrm{M})$, a cell-permeable cAMP analogue. The concentration of cpt-cAMP was chosen based on previous dose response data (not shown) to determine whether PAF elicits additional current after maximum activation by cAMP, the best-characterized regulator of ion transport in this cell line $(18,19)$. The order was varied to see whether there was any cumulative effect (Fig. 1a). PAF $(10 \mu \mathrm{M})$ alone stimulated a $\Delta \mathrm{I}_{\mathrm{sc}}$ to a maximum of $22.0 \pm 2.8 \mu \mathrm{A} / \mathrm{cm}^{2}$, followed by decay to a stable $4.5 \pm 0.7 \mu \mathrm{A} / \mathrm{cm}^{2} \Delta \mathrm{I}_{\mathrm{sc}}$, which persisted for $>30$ min. PAF added after maximally activated cAMP-induced current resulted in an additional $17.7 \pm 3.3 \mu \mathrm{A} / \mathrm{cm}^{2}$ current. A chloride channel blocker, glybenclamide $(500 \mu \mathrm{M})$, added to the mucosal side returned $I_{\mathrm{sc}}$ to the baseline level, suggesting that $\mathrm{Cl}^{-}$is the principal charge carrier in these effects $(n=$ $6-10)$.

The dose dependence of PAF-stimulated $I_{\text {sc }}$ Previously published reports on PAF-mediated changes in various cell types demonstrate two very distinct ranges of dose responses. Effective doses in the 1-100 $\mu \mathrm{M}$ range have been observed primarily in epithelial tissues (20-23), whereas other cell lines exhibit several orders of magnitude higher sensitivity to PAF, in the $10-500 \mathrm{nM}$ range (24-26). To correlate our observations with these earlier studies, we evaluated the dose response relationship of PAF-elicited $I_{s c}$ in HT29-CL19A cells. PAF regulated ion transport at doses ranging from 0.1 to $200 \mu \mathrm{M}$ in this cell line (Fig. 1b). Vehicle alone (ethanol) had no effect on
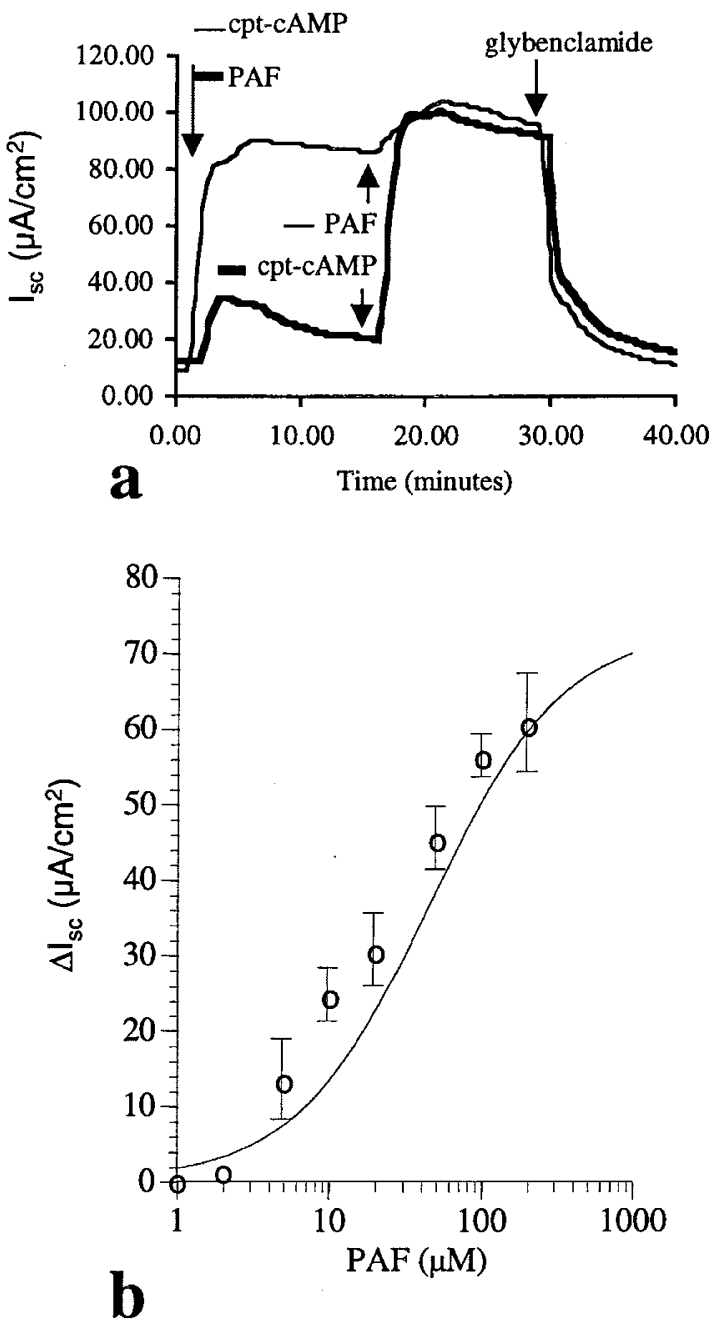

Figure 1. Regulation of $I_{s c}$ by PAF in HT29-CL19A cells. HT29-CL19A cells were mounted in Ussing chambers and $\mathrm{I}_{\mathrm{se}}$ was recorded. Panel a shows representative current traces of $\mathrm{I}_{\mathrm{sc}}$ after sequential addition of either $10 \mu \mathrm{M}$ PAF followed by $300 \mu \mathrm{M}$ cAMP (thick line) or $300 \mu \mathrm{M}$ cAMP followed by $10 \mu \mathrm{M}$ PAF (thin line) and finished with the addition of $500 \mu \mathrm{M}$ glybenclamide. Arrows indicate the time of treatments. Panel $b$ depicts $\Delta \mathrm{I}_{\mathrm{sc}}$ (max) as a function of the PAF concentration applied to filter-grown HT29-CL19A cells mounted in Ussing chambers. Curve was fitted to the data points using the Michaelis-Menten equation. Each data point represents mean $\pm \mathrm{SEM}$ for $n=$ 4-10 experiments. Calculated $\mathrm{K}_{\mathrm{s}}=46 \mu \mathrm{M}, R^{2}=0.91$.

$\mathrm{I}_{\mathrm{sc}}$ (not shown). Curve fitting to the results of dose response observations using the Michaelis-Menten equation revealed a $\mathrm{K}_{\mathrm{s}}$ for PAF-induced $\mathrm{I}_{\mathrm{sc}}$ of $46 \mu \mathrm{M}\left(R^{2}=0.91\right)$.

Identification of the charge carrier responsible for PAF currents. To investigate more thoroughly the charge carrier associated with PAF-induced currents, we influenced the driving forces for chloride in our system, and evaluated the effects of chloride channel inhibitors on the current. Low-chloride (7.6 $\mathrm{mM}$ ) buffer was prepared by substituting sodium gluconate for $\mathrm{NaCl}$ in the standard physiologic buffer. The effect of PAF on $\mathrm{I}_{\mathrm{sc}}$ was measured with or without permeabilization of the basolateral membrane with $100 \mu \mathrm{M}$ amphotericin B for $30 \mathrm{~min}$ before the addition of other agents, and in the presence of a chloride gradient across the monolayer. The chloride gradient was created by placing low $\mathrm{Cl}^{-}$buffer in either the serosal or 
the mucosal chamber, while maintaining physiologic $\mathrm{Cl}^{-}$concentration in the opposing chamber. PAF added in the presence of serosal amphotericin and a serosal to mucosal $\mathrm{Cl}^{-}$gradient resulted in a $30.5 \pm 2.4 \mu \mathrm{A} / \mathrm{cm}^{2} \Delta \mathrm{I}_{\mathrm{sc}}$, whereas reversal of the gradient in the presence of serosal amphotericin resulted in a reversed current $-13.5 \pm 1.7 \mu \mathrm{A} / \mathrm{cm}^{2}$ (Fig. 2a). To ensure that the PAF-induced current was not due to changes in paracellular conductance, the effect of PAF on $\mathrm{I}_{\mathrm{sc}}$ was also evaluated without permeabilization of the basolateral membrane. As depicted by the dashed line in Figure $2 a$, PAF did not elicit any detectable change in $\mathrm{I}_{\mathrm{sc}}\left(-0.47 \pm 0.05 \mu \mathrm{A} / \mathrm{cm}^{2}, n=6\right)$ when low $\mathrm{Cl}^{-}$buffer was placed in the serosal chamber without permeabilization of the basolateral membrane, indicating that PAF-induced current is due to transcellular, and not paracellular ion transport. The $\mathrm{Cl}^{-}$channel blockers glybenclamide $(500 \mu \mathrm{M})$, DPC $(500 \mu \mathrm{M})$, and DIDS $(600 \mu \mathrm{M})$ blocked PAF-induced stable $\Delta \mathrm{I}_{\mathrm{sc}}$ by $81 \pm 8 \%, 80 \pm 9 \%$, and $80.6 \pm$
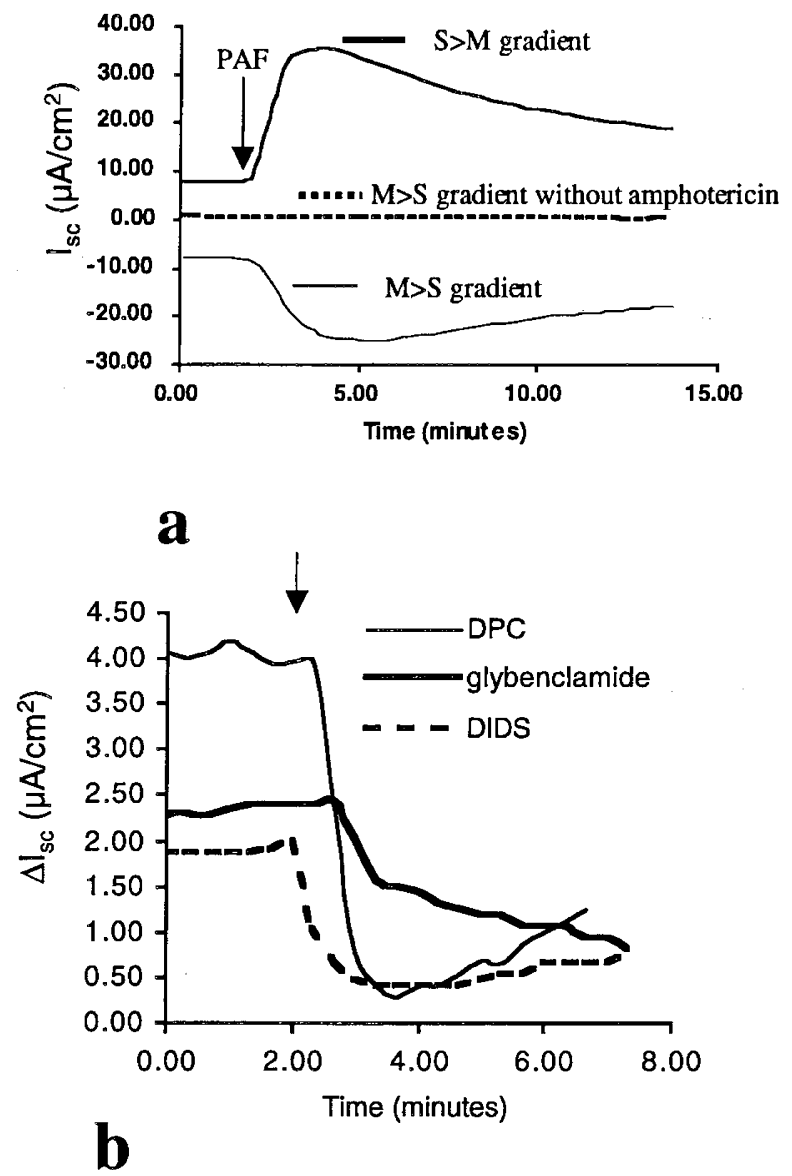

Figure 2. Identification of the charge carrier for PAF-stimulated $\mathrm{I}_{\mathrm{sc}}$. Filtergrown HT29-CL19A cells were mounted in Ussing chambers and $\mathrm{I}_{\mathrm{sc}}$ was recorded. Panel $a$ shows $\mathrm{I}_{\mathrm{sc}}$ tracings from a representative experiment comparing PAF stimulated $I_{s c}$ after permeabilization of the serosal plasma membrane in the presence of a serosal to mucosal $\mathrm{Cl}^{-}$gradient across the monolayer (thick line) or a mucosal to serosal gradient (thin line). Dashed line illustrates a lack of PAF effect in the presence of a mucosal to serosal $\mathrm{Cl}^{-}$ gradient when the basolateral membrane was not permeabilized by amphotericin B. Arrow indicates time of PAF addition. Panel $b$ shows representative $\mathrm{I}_{\mathrm{sc}}$ tracings depicting the effect of the $\mathrm{Cl}^{-}$channel blockers DPC $(500 \mu \mathrm{M})$, glybenclamide $(500 \mu \mathrm{M})$, and DIDS $(600 \mu \mathrm{M})$ on PAF-induced $\Delta \mathrm{I}_{\mathrm{sc}}$ after stabilization of current. Arrow indicates time of addition of inhibitors.
$9.2 \%$, respectively (Fig. $2 b$, all significant at $p<0.05, n=4$ ). All three inhibitors were added only in the mucosal chamber, with simultaneous addition of solvent to the opposing chamber to avoid an effect on basolateral transporters. Solvents added to both sides had no significant effect, and none of the channel blockers affected baseline currents (data not shown).

$P A F$ stimulates $I_{\text {sc }}$ directly and specifically in HT29CL19A cells. PAF can be metabolized in various ways, and its by-products may affect ion transport. HT29-CL19A monolayers were treated with the PAF analogue carbamyl PAF (27) or with PAF in the presence of the degrading enzyme PAF-AH (28) to confirm a direct and specific effect of PAF on $\mathrm{I}_{\mathrm{sc}}$. Carbamyl PAF at $10 \mu \mathrm{M}$ elicited $27.6 \pm 2.6 \mu \mathrm{A} / \mathrm{cm}^{2} \Delta \mathrm{I}_{\mathrm{sc}}$, whereas including PAF-AH in the chamber before adding PAF blocked PAF-induced $\Delta \mathrm{I}_{\mathrm{sc}}$ to $2.6 \pm 1.1 \mu \mathrm{A} / \mathrm{cm}^{2}(p<0.05, n$ $=4$ ).

The stimulation of $\mathrm{Cl}^{-}$transport by $\mathrm{PAF}$ is not mediated by prostaglandin synthesis. Earlier studies indicating that $\mathrm{PAF}$ applied to the serosal side of intestinal explants stimulates $\mathrm{Cl}^{-}$ transport found that this stimulatory effect required prostaglandin synthesis, and, therefore, was blocked by indomethacin. Although the stimulation of transepithelial $\mathrm{Cl}^{-}$transport by PAF exhibited very different characteristics, to further differentiate the direct mucosal activation of $\mathrm{I}_{\mathrm{sc}}$ by PAF from the previously described serosal indirect effect, we evaluated the potential role of prostaglandin synthesis. After pretreatment and the subsequent continuous presence of $10 \mu \mathrm{M}$ indomethacin, both the time course and magnitude of PAF-stimulated $\mathrm{I}_{\mathrm{sc}}$ was indistinguishable from $\mathrm{I}_{\mathrm{sc}}$ in the absence of indomethacin (Fig. 3, $a$ and $b$ ). Interestingly, indomethacin caused a small but significant increase in the cAMP-stimulated $\mathrm{I}_{\mathrm{sc}}$.

The effect of PAFR antagonists on PAF-induced $I_{s c}$ Given that the sensitivity of PAF-dependent activation of ion transport in epithelial cells is strikingly different from the activation of PAFR in endometrial cells, $\mathrm{T}$ and B lymphocytes, and macrophages, we evaluated the effect of PAFR antagonists to confirm a specific PAFR-mediated effect. CV6209 $(20 \mu \mathrm{M})$ and octylonium bromide $(40 \mu \mathrm{M})$ almost completely abolished the stimulation of $\mathrm{I}_{\mathrm{sc}}$ by $20 \mu \mathrm{M}$ PAF (Fig. $4 a$ ). PAF alone induced $26.4 \pm 3.0 \mu \mathrm{A} / \mathrm{cm}^{2} \Delta \mathrm{I}_{\mathrm{sc}}(n=10)$, whereas pretreatment with CV6209 or octylonium bromide reduced PAFinduced $\Delta \mathrm{I}_{\mathrm{sc}}$ to $4.0 \pm 1.3 \mu \mathrm{A} / \mathrm{cm}^{2}$ and $4.7 \pm 2.6 \mu \mathrm{A} / \mathrm{cm}^{2}$, respectively $(p<0.01)$. Neither receptor antagonist had a significant effect on cAMP-induced ion transport in HT29CL19A cells, indicating a specific inhibitory effect on PAFinduced ion transport.

PAF stimulates $I_{s c}$ only when added to the mucosal surface of HT29-CL19A monolayers. To determine the polarity of PAF-induced $\mathrm{I}_{\mathrm{sc}}$, PAF was added to either the mucosal or serosal chamber and resulting $\mathrm{I}_{\mathrm{sc}}$ changes were recorded and quantified. When PAF $(10 \mu \mathrm{M})$ was only added to the mucosal side of the monolayer, mean $\Delta \mathrm{I}_{\mathrm{sc}}$ was $35.0 \pm 5.2 \mu \mathrm{A} / \mathrm{cm}^{2}$, whereas PAF $(10 \mu \mathrm{M})$ added only to the serosal chamber resulted in no current $\left(\Delta \mathrm{I}_{\mathrm{sc}}=0.2 \pm 0.1 \mu \mathrm{A} / \mathrm{cm}^{2}\right.$, Fig. $\left.4 b\right)$.

Analysis of PAFR expression and polarity. We next tested whether HT29-CL19A cells express the same PAFR identified in other cell types. Total RNA was isolated from cultured cells and analyzed by reverse-transcriptase (RT)-PCR using primers 

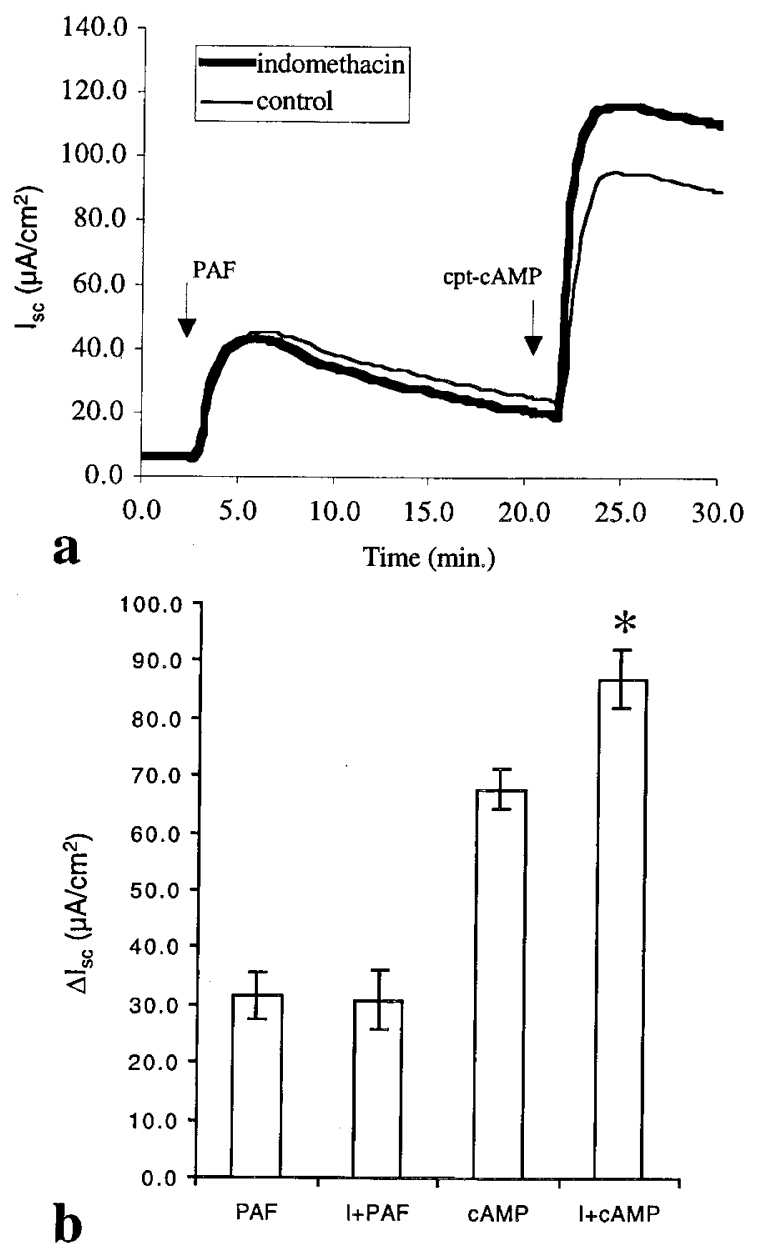

Figure 3. Prostaglandin synthesis is not required for the induction of $\mathrm{Cl}^{-}$ transport by PAF from the mucosal side of the epithelial monolayer. Filtergrown HT29-CL19A monolayers were mounted in Ussing chambers. Panel a depicts a representative $I_{s c}$ trace in which cells were treated with $10 \mu \mathrm{M}$ indomethacin to block prostaglandin synthesis, $\mathrm{I}_{\mathrm{sc}}$ was recorded and PAF (20 $\mu \mathrm{M})$ was added followed by cAMP $(300 \mu \mathrm{M})$ as indicated by arrows. Panel $b$ illustrates the mean \pm SEM change of $\mathrm{I}_{\mathrm{sc}}$ elicited by indomethacin treated, and untreated HT29-CL19A monolayers $(n=6)$. ${ }^{*} p<0.05$.

designed to hybridize with the known human PAFR. The authenticity of PCR products was verified using restriction digest mapping. Figure $5 a$ illustrates that HT29-CL19A cells constitutively express PAFR transcripts as shown by amplification of the predicted $549 \mathrm{bp}$ fragment by RT-PCR. The fragment was cut by $P v u I I$ ( $417 \mathrm{bp}$ and $132 \mathrm{bp}$ ), and $A v a \mathrm{II}$ (427 $\mathrm{bp}$ and $122 \mathrm{bp}$ ), as predicted based on the published sequence (29).

We then used domain-selective biotinylation to detect PAFR present on either the apical or basolateral plasma membrane. On streptavidin blots, the characteristic PAFR $68-\mathrm{kD}$ band (15, 30) was detected from lysates of cells that were exposed to the biotinylating agent on their apical surface (Fig. 5b). The correct-size protein band was not detected from cell lysates that were not exposed to the biotinylating reagent, or when nonimmune IgG was used instead of the anti-PAFR antibody. In addition, this band was not detected from cells biotinylated from the basolateral side; only a faint lower molecular weight band was detected that was also present in the nonimmune

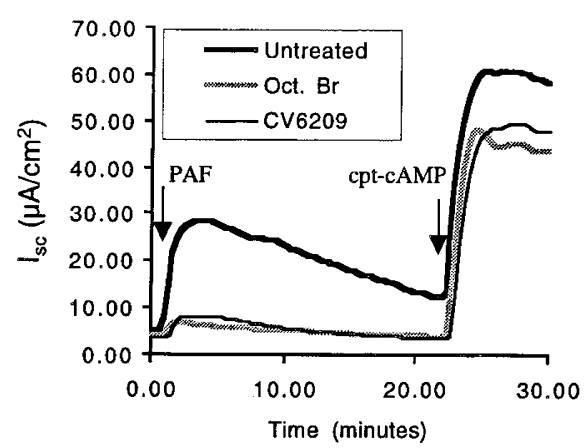

$\mathbf{a}$

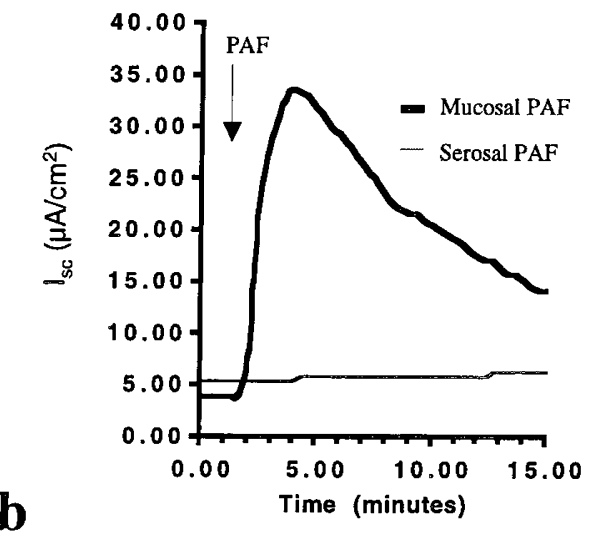

Figure 4. Analysis of specificity and sidedness of PAF-induced $\mathrm{I}_{\mathrm{sc}}$. Filtergrown HT29-CL19A monolayers were mounted in Ussing chambers. Panel a depicts a representative $I_{s c}$ trace in which cells were treated with $20 \mu \mathrm{M}$ CV6209 or $40 \mu \mathrm{M}$ octylonium bromide to desensitize PAFR, then $\mathrm{I}_{\mathrm{sc}}$ was recorded and PAF $(20 \mu \mathrm{M})$ was added followed by cAMP $(300 \mu \mathrm{M})$. Panel $b$ : HT29-CL19A cells were mounted in Ussing chambers, and $\mathrm{I}_{\mathrm{sc}}$ was recorded. Arrow indicates the addition of $10 \mu \mathrm{M}$ PAF into either the serosal chamber (thin line) or mucosal chamber (thick line).

control. Polymeric IGR was used as a positive control to confirm biotinylation of basolateral proteins across the supporting membrane (Fig. 5c).

\section{DISCUSSION}

Vectorial ion transport is one of the hallmark functions of intestinal epithelium. $\mathrm{Na}^{+}$and $\mathrm{Cl}^{-}$are the two solutes transported in the largest quantities, and disordered $\mathrm{Cl}^{-}$secretion is the basis for several diseases. Exaggerated $\mathrm{Cl}^{-}$secretion causes the severe secretory diarrhea associated with Vibrio cholerae and Escherichia coli toxins. Conversely, when $\mathrm{Cl}^{-}$ secretion is impaired, as in cystic fibrosis, an intestinal obstruction such as meconium ileus can result (31). In addition, $\mathrm{Cl}^{-}$ secretion has been thought to be a participant in innate mucosal defense mechanisms against bacteria (32).

A number of inflammatory mediators have been shown to regulate $\mathrm{Cl}^{-}$transport either by regulating the activity of ion channels, or by regulating their gene expression. PAF, a phospholipid mediator that has been implicated in the pathology of NEC, IBD, and asthma $(2,3,33)$, has been shown to activate $\mathrm{Cl}^{-}$transport in both intestinal explants and airway epithelial 


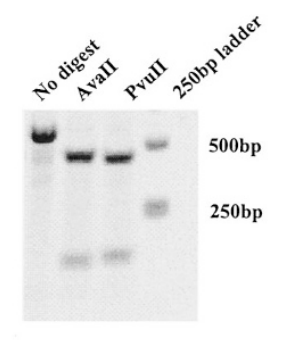

a

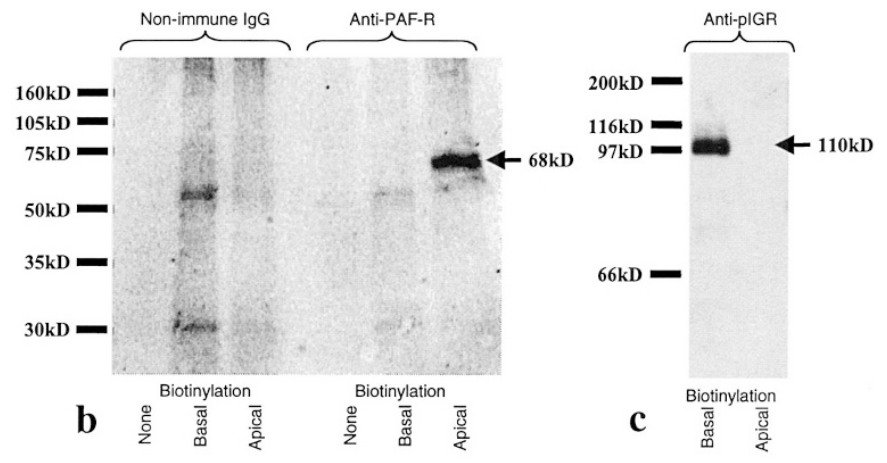

Figure 5. Analysis of PAFR expression and polarity in HT29-CL19A cells. Panel $a$ illustrates the results of RT-PCR and restriction digest mapping analysis of PAFR mRNA in HT29-CL19A cells. Total RNA was extracted from the HT29-CL19A cell line and amplified by RT-PCR for PAFR mRNA. After PCR, PAFR PCR products were digested with PuvII or AvaII restriction enzymes and separated by electrophoresis on a $1.2 \%$ agarose gel. The 549 -bp band in the undigested sample, the 417-bp/132-bp fragments by $P v u$ II digestion and the 427-bp/122-bp fragments by AvaII digestion correspond to the sizes predicted based on the published sequence. Panel $b$ : Domain-selective biotinylation, immunoprecipitation, and streptavidin blotting of PAFR. Filtergrown HT29-CL19A cells were biotinylated either from the mucosal or serosal direction, and then cell lysates were immunoprecipitated using a PAFR antibody and blotted with streptavidin. The image depicts a representative biotin-streptavidin blot of immunoprecipitated PAFR and corresponding unbiotinylated and/or nonimmune controls as indicated. The arrow points to the characteristic 68 -kD PAFR band only observed in cells with domain-selective biotinylation of the mucosal surface. Panel $c$ : Verification of successful biotinylation of basolateral proteins. Immunoprecipitation performed using a monoclonal anti pIGR. The characteristic $110-\mathrm{kD}$ band was observed only in samples biotinylated from the serosal side. This experiment was repeated three times with similar results.

cells. To date, direct effects of PAF on ion transport of epithelial monolayers have been demonstrated only in airway epithelial cells (20). The direct effect by PAF on airway epithelial cells has been demonstrated at micromolar concentrations and elicited from the mucosal side of the monolayers. The effect on intestinal transport has been thought to be mediated only indirectly via the stimulated production of mediators such as prostaglandins $(12,21)$ and thromboxanes $(13)$. The indirect effect of PAF on intestinal explants has only been observed from the serosal side at nanomolar concentrations. Merendino et al. (15) have previously demonstrated PAFR expression in the intestinal epithelium, and several studies have documented increased stool PAF content in patients with IBD compared with disease-free controls. Given the high-level expression of PAFR in the intestinal epithelium, we hypothesized that, in addition to previously documented indirect effects, PAF would have a direct effect on intestinal epithelial cells.
The purpose of our study was to characterize the role of PAF in the direct regulation of intestinal epithelial cell ion transport. We performed our experiments in the HT29CL19A cell line; a well-described transformed human colonic crypt cell model $(16,34)$. Our results demonstrate that PAF stimulates $\mathrm{Cl}^{-}$transport across monolayers of HT29CL19A cells. PAF-induced $I_{\text {sc }}$ followed the direction of a $\mathrm{Cl}^{-}$gradient when basolateral plasma membranes were permeabilized, and was inhibited by the $\mathrm{Cl}^{-}$channel blockers glybenclamide, DPC, and DIDS. On the other hand, without the permeabilization of the basolateral plasma membrane and in the presence of a mucosal to serosal $\mathrm{Cl}^{-}$ gradient, PAF did not elicit any current, excluding the possibility that increased paracellular permeability is responsible for the observed current. All three $\mathrm{Cl}^{-}$channel blockers inhibited PAF-induced $\mathrm{I}_{\mathrm{sc}}$, even when only added to the mucosal compartment and in cells with permeabilized basolateral membranes, indicating that this inhibition was not a result of interference with basolateral loading mechanisms. The elicited PAF $\mathrm{I}_{\mathrm{sc}}$ was not affected by indomethacin, confirming a direct effect not requiring prostaglandin synthesis. Thus, our results indicate that PAF-induced $\mathrm{I}_{\mathrm{sc}}$ results from the opening of a chloride channel in the apical cell membrane, and represents vectorial $\mathrm{Cl}^{-}$transport in a serosal to mucosal direction. Several $\mathrm{Cl}^{-}$channels have been identified in intestinal cells and the precise identification of the ion channel opened after activation by PAF was beyond the scope of this study. Further studies using techniques such as patch clamping and single-channel analysis may be helpful in identifying the specific $\mathrm{Cl}^{-}$channel opened by PAF.

All of our observations suggest that in HT29-CL19A cells, PAF activates $\mathrm{Cl}^{-}$transport via a specific receptor-mediated effect. We confirmed the presence of PAFR mRNA in HT29CL19A cells by RT-PCR and the PAFR protein by immunoprecipitation and streptavidin blotting of the biotinylated receptor. The effect of PAF on $\mathrm{I}_{\mathrm{sc}}$ was mimicked by carbamylPAF, a nonmetabolizable analogue of PAF, was abolished by PAF-AH, a PAF degrading enzyme, and was inhibited by the PAFR antagonists CV6209 and octylonium bromide. The PAFR antagonists did not have an effect on cAMP-induced $\mathrm{I}_{\mathrm{sc}}$, verifying the specificity of their effect. Furthermore, the observed apical polarity of the PAFR protein was consistent with the functional effect, i.e. PAF activated $\mathrm{I}_{\mathrm{sc}}$ only from the mucosal chamber.

Yet, as previously mentioned, significant differences exist between PAF-induced effects in epithelial cells compared with PAFR activation in other cell types. We observed stimulation of ion transport by PAF at micromolar concentrations in cultured intestinal epithelial cells similar to that seen in cultured bronchial epithelial cells (20), but different from the high-affinity activation identified in Chinese hamster ovary cells transfected with PAFR, endometrial cells, T and B lymphocytes, primary hippocampal neurons, macrophages $(24-26,35)$, and the indirect serosal effects observed in rat and human tissue explants $(12,13)$. The mechanism reducing the affinity of PAFR to its ligand in the apical plasma membranes of intestinal and airway epithelial cells 
compared with other nonepithelial cells is unknown. Experimental evidence suggests that $G$ proteins or membrane lipids can modify the affinity of PAF to PAFR. When the receptor is bound to heterotrimeric $G$ proteins, it exhibits high PAF affinity, but this affinity is reduced when the $G$ proteins dissociate (36). Also, treatment of PAFRexpressing cells with polyunsaturated fatty acids that alter the lipid composition of extracted membranes changes the binding affinity of PAF to PAFR (37). Therefore, either the profile of associated heterotrimeric $G$ proteins or the surrounding lipids could influence the affinity of PAFR to PAF in different cell types. Alternatively, a second, low-affinity binding site might exist on the PAFR that could explain the effects observed exclusively in cultured epithelial cells.

The in vivo relevance of low-affinity PAFR on the intestinal mucosal surface may be controversial. Although there is no information available regarding the exact concentrations of PAF at the mucosal surfaces of intestinal epithelial cells, it is likely that relatively high concentrations might exist, especially under pathologic conditions. The two key enzymes involved in the biosynthesis of PAF, the secretory form of type II phospholipase $\mathrm{A}_{2}$ and PAF acetyltransferase, have both been shown to be expressed by intestinal epithelial cells $(38,39)$. Type II phospholipase $\mathrm{A}_{2}$ is expressed in Paneth cells, and its expression is increased in ulcerative colitis (38). Indeed, cultured colonic biopsies from ulcerative colitis patients have been shown to produce PAF (40) at $0.8 \mathrm{nmol} / \mathrm{g}_{\text {(tissue) }} / \mathrm{h}$ rates. In another study, tissue concentrations of PAF in micromolar concentrations were found in mucosal scrapings of biopsy specimens from patients with ulcerative colitis (41). Escherichia coli and other bacteria that are commonly found in the gastrointestinal tract are also extremely capable of producing PAF $(42,43)$. PAF can be readily detected in stool from patients with ulcerative colitis and Crohn's disease (2). Considering that the PAFdegrading enzyme PAF acetylhydrolase is present in the intestinal lumen, any detectable PAF in the stool suggests potentially much higher concentrations upstream in the intestinal tract. Therefore, a low-affinity PAFR in the luminal plasma membrane of epithelial cells might indicate an adaptation specifically designed to be activated only under potentially high levels of PAF that might exist under pathologic conditions in the intestinal lumen.

In conclusion, PAF directly and specifically stimulates $\mathrm{Cl}^{-}$ transport in intestinal epithelial cells through the opening of an apical chloride channel. This direct stimulation of $\mathrm{Cl}^{-}$transport can be elicited only by mucosal application of PAF, and the polarity of the functional effect correlates with our observation that PAFR is expressed in the apical domain of polarized HT29-CL19A cells. PAF-induced $\mathrm{Cl}^{-}$transport may represent a physiologic function, or may be related to PAFinduced mucosal injury. Further studies of the direct interactions of epithelial cells with PAF leading to a better understanding of the physiologic and pathologic roles of PAF in mucosal homeostasis may elucidate mechanisms of intestinal injury resulting from altered PAF metabolism.

\section{REFERENCES}

1. Caplan MS, MacKendrick W 1993 Necrotizing enterocolitis: a review of pathogenetic mechanisms and implications for prevention. Pediatr Pathol 13:357-369

2. Hocke M, Richter L, Bosseckert H, Eitner K 1999 Platelet activating factor in stool from patients with ulcerative colitis and Crohn's disease. Hepatogastroenterology 46:2333-2337

3. Caplan MS, Hsueh W 1990 Necrotizing enterocolitis: role of platelet activating factor, endotoxin, and tumor necrosis factor. J Pediatr 117

4. Hsueh W, Gonzalez-Crussi F, Arroyave JL 1987 Platelet-activating factor: an endogenous mediator for bowel necrosis in endotoxemia. FASEB J 1:403-405

5. Caplan MS, Hedlund E, Adler L, Lickerman M, Hsueh W 1997 The plateletactivating factor receptor antagonist WEB 2170 prevents neonatal necrotizing enterocolitis in rats. J Pediatr Gastroenterol Nutr 24:296-301

6. Hsueh W, Gonzalez-Crussi F, Arroyave JL, Anderson RC, Lee ML, Houlihan WJ 1986 Platelet activating factor-induced ischemic bowel necrosis: the effect of PAF antagonists. Eur J Pharmacol 123:79-83

7. Kald B, Smedh K, Olaison G, Sjodahl R, Tagesson C 1996 Platelet-activating factor acetylhydrolase activity in intestinal mucosa and plasma of patients with Crohn's disease. Digestion 57:472-477

8. Meenan J, Grool TA, Hommes DW, Dijkhuizen S, ten Kate FJ, Wood M, Whittaker M, Tytgat GN, van Deventer SJ 1996 Lexipafant (BB-882), a platelet activating factor receptor antagonist, ameliorates mucosal inflammation in an animal model of colitis. Eur J Gastroenterol Hepatol 8:569-573

9. Halm DR, Halm ST 2000 Secretagogue response of goblet cells and columnar cells in human colonic crypts. Am J Physiol 278:C212-C233

10. Sakai H, Sato T, Hamada N, Yasue M, Ikari A, Kakinoki B, Takeguchi N 1997 Thromboxane $\mathrm{A}_{2}$, released by the anti-tumour drug irinotecan, is a novel stimulator of $\mathrm{Cl}^{-}$secretion in isolated rat colon. J Physiol (Lond) 505:133-144

11. Hanglow AC, Bienenstock J, Perdue MH 1989 Effects of platelet-activating factor on ion transport in isolated rat jejunum. Am J Physiol 257:G845-G850

12. Borman RA, Jewell R, Hillier K 1998 Investigation of the effects of platelet-activating factor (PAF) on ion transport and prostaglandin synthesis in human colonic mucosa in vitro. Br J Pharmacol 123:231-236

13. Suzuki T, Sakai H, Takeguchi N 2000 Thromboxane $\mathrm{A}_{2}$-mediated $\mathrm{Cl}^{-}$secretion induced by platelet-activating factor in isolated rat colon. Eur J Pharmacol 400:297303

14. Travis SP, Jewell DP 1992 Regional differences in the response to platelet-activating factor in rabbit colon. Clin Sci (Colch) 82:673-680

15. Merendino N, Dwinell MB, Varki N, Eckmann L, Kagnoff MF 1999 Human intestinal epithelial cells express receptors for platelet-activating factor. Am J Physiol 277:G810-G818

16. Augeron C, Laboisse CL 1984 Emergence of permanently differentiated cell clones in a human colonic cancer cell line in culture after treatment with sodium butyrate. Cancer Res 44:3961-3969

17. Chau LY, Peck K, Yen HH, Wang JY 1994 Agonist-induced down-regulation of platelet-activating factor receptor gene expression in U937 cells. Biochem J 301:911916

18. Rogers KV, Goldman PS, Frizzell RA, McKnight GS 1990 Regulation of $\mathrm{Cl}^{-}$ transport in $\mathrm{T}_{84}$ cell clones expressing a mutant regulatory subunit of cAMPdependent protein kinase. Proc Natl Acad Sci U S A 87:8975-8979

19. Bajnath RB, Augeron C, Laboisse CL, Bijman J, de Jonge HR, Groot JA 1991 Electrophysiological studies of forskolin-induced changes in ion transport in the human colon carcinoma cell line HT-29 cl.19A: lack of evidence for a cAMPactivated basolateral $\mathrm{K}^{+}$conductance. J Membr Biol 122:239-250

20. Tamaoki J, Sakai N, Isono K, Kanemura T, Yamawaki I, Takizawa T 1991 Effects of platelet-activating factor on bioelectric properties of cultured tracheal and bronchial epithelia. J Allergy Clin Immunol 87:1042-1049

21. Bern MJ, Sturbaum CW, Karayalcin SS, Berschneider HM, Wachsman JT, Powell DW 1989 Immune system control of rat and rabbit colonic electrolyte transport. Role of prostaglandins and enteric nervous system. J Clin Invest 83:1810-1820

22. Klettke U, Luck W, Wahn U, Niggemann B 1999 Platelet-activating factor inhibits ciliary beat frequency of human bronchial epithelial cells. Allergy Asthma Proc 20:115-118

23. Matsumoto K, Hashimoto S, Gon Y, Nakayama T, Horie T 1998 Proinflammatory cytokine-induced and chemical mediator-induced IL-8 expression in human bronchial epithelial cells through p38 mitogen-activated protein kinase-dependent pathway. J Allergy Clin Immunol 101:825-831

24. Kravchenko VV, Pan Z, Han J, Herbert JM, Ulevitch RJ, Ye RD 1995 Plateletactivating factor induces NF- $\kappa \mathrm{B}$ activation through a $\mathrm{G}$ protein-coupled pathway. J Biol Chem 270:14928-14934

25. Huang YH, Schafer-Elinder L, Owman H, Lorentzen JC, Ronnelid J, Frostegard J 1996 Induction of IL-4 by platelet-activating factor. Clin Exp Immunol 106:143-148

26. Bonaccorsi L, Luconi M, Maggi M, Muratori M, Forti G, Serio M, Baldi E 1997 Protein tyrosine kinase, mitogen-activated protein kinase and protein kinase $\mathrm{C}$ are involved in the mitogenic signaling of platelet-activating factor (PAF) in HEC-1A cells. Biochim Biophys Acta 1355:155-166

27. Travers JB, Li Q, Sprecher H, Fertel RH 1992 Binding of carbamyl-platelet-activating factor to the Raji lymphoblast platelet-activating factor receptor. Int J Immunopharmacol 14:515-523

28. Stafforini DM, McIntyre TM, Carter ME, Prescott SM 1987 Human plasma plateletactivating factor acetylhydrolase. Association with lipoprotein particles and role in the degradation of platelet-activating factor. J Biol Chem 262:4215-4222

29. Nakamura M, Honda Z, Izumi T, Sakanaka C, Mutoh H, Minami M, Bito H, Seyama Y, Matsumoto T, Noma M 1991 Molecular cloning and expression of plateletactivating factor receptor from human leukocytes. J Biol Chem 266:20400-20405 
30. Muller E, Dagenais P, Alami N, Rola-Pleszczynski M 1993 Identification and functional characterization of platelet-activating factor receptors in human leukocyte populations using polyclonal anti-peptide antibody. Proc Natl Acad Sci U S A 90:5818-5822

31. O'Loughlin EV, Hunt DM, Gaskin KJ, Stiel D, Bruzuszcak IM, Martin HC, Bambach C, Smith R 1991 Abnormal epithelial transport in cystic fibrosis jejunum. Am J Physiol 260:G758-G763

32. Goldman MJ, Anderson GM, Stolzenberg ED, Kari UP, Zasloff M, Wilson JM 1997 Human $\beta$-defensin- 1 is a salt-sensitive antibiotic in lung that is inactivated in cystic fibrosis. Cell 88:553-560

33. Stafforini DM, Numao T, Tsodikov A, Vaitkus D, Fukuda T, Watanabe N, Fueki N, McIntyre TM, Zimmerman GA, Makino S, Prescott SM 1999 Deficiency of plateletactivating factor acetylhydrolase is a severity factor for asthma. J Clin Invest 103:989-997

34. van den Berghe N, Vaandrager AB, Bot AG, Parker PJ, de Jonge HR 1992 Dual role for protein kinase $\mathrm{C}$ alpha as a regulator of ion secretion in the HT29cl.19A human colonic cell line. Biochem J 285:673-679

35. Mukherjee PK, DeCoster MA, Campbell FZ, Davis RJ, Bazan NG 1999 Glutamate receptor signaling interplay modulates stress-sensitive mitogen-activated protein kinases and neuronal cell death. J Biol Chem 274:6493-6498

36. Carlson SA, Chatterjee TK, Murphy KP, Fisher RA 1998 Mutation of a putative amphipathic alpha-helix in the third intracellular domain of the platelet-activating factor receptor disrupts receptor/G protein coupling and signaling. Mol Pharmacol 53:451-458

37. Kang JX, Man SF, Hirsh AJ, Clandinin MT 1994 Characterization of plateletactivating factor binding to human airway epithelial cells: modulation by fatty acids and ion-channel blockers. Biochem J 303:795-802

38. Haapamaki MM, Gronroos JM, Nurmi H, Alanen K, Kallajoki M, Nevalainen TJ 1997 Gene expression of group II phospholipase $A_{2}$ in intestine in ulcerative colitis. Gut 40:95-101

39. Kald B, Boll RM, Gustafson-Svard C, Sjodahl R, Tagesson C 1994 Phospholipase C from Clostridium perfringens stimulates acetyltransferase-dependent formation of platelet-activating factor in cultured intestinal epithelial cells (INT 407). Scand J Gastroenterol 29:243-247

40. Wardle TD, Hall L, Turnberg LA 1996 Platelet activating factor: release from colonic mucosa in patients with ulcerative colitis and its effect on colonic secretion. Gut 38:355-361

41. Thyssen E, Turk J, Bohrer A, Stenson WF 1996 Quantification of distinct molecular species of platelet activating factor in ulcerative colitis. Lipids 31(suppl):S255-S259

42. Denizot Y, Dassa E, Benveniste J, Thomas Y 1989 PAF-acether production by Escherichia coli. Biochem Biophys Res Commun 161:939-943

43. Denizot Y, Sobhani I, Rambaud JC, Lewin M, Thomas Y, Benveniste J 1990 PAF-acether synthesis by Helicobacter pylori. Gut 31:1242-1245 